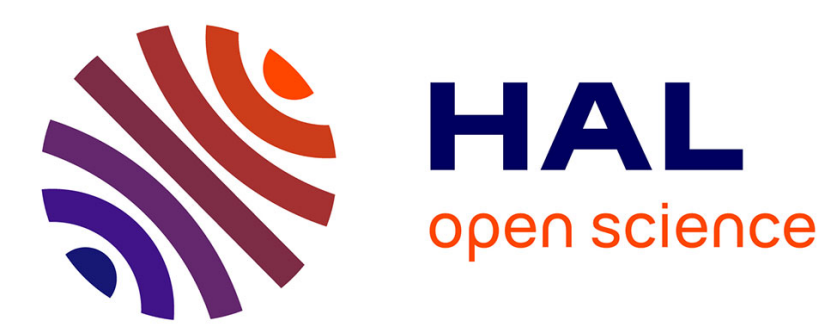

\title{
Three-Strikes Response to Copyright Infringement: The Case of HADOPI
}

Primavera de Filippi, Danièle Bourcier

\section{To cite this version:}

Primavera de Filippi, Danièle Bourcier. Three-Strikes Response to Copyright Infringement: The Case of HADOPI. Francesca Musiani, Derrick L. Cogburn, Laura DeNardis, Nanette S. Levinson. The Turn to Infrastructure in Internet Governance, Palgrave-Macmillan, pp.125-152, 2016, 978-1-349-57846-7. 10.1057/9781137483591_7. hal-01382009

\section{HAL Id: hal-01382009 \\ https://hal.science/hal-01382009}

Submitted on 22 Feb 2019

HAL is a multi-disciplinary open access archive for the deposit and dissemination of scientific research documents, whether they are published or not. The documents may come from teaching and research institutions in France or abroad, or from public or private research centers.
L'archive ouverte pluridisciplinaire HAL, est destinée au dépôt et à la diffusion de documents scientifiques de niveau recherche, publiés ou non, émanant des établissements d'enseignement et de recherche français ou étrangers, des laboratoires publics ou privés. 


\title{
Three-Strikes Response to Copyright Infringement: The Case of HADOPI
}

\author{
Primavera De Filippi, Danièle Bourcier \\ CERSA - CNRS
}

Another notable example of how copyright enforcement has moved well beyond addressing specific infringing content or individuals into Internet governance-based infrastructural enforcement is the graduated response method, terminating the Internet access of individuals that (allegedly and) repeatedly violate copyright. The case of the French Hadopi (Haute Autorite pour la Diffusion des Euvres et la Protection des droits sur Internet), law first, agency next, both highly controversial, illustrates this strategy of dubious effectiveness for the purpose it is meant for, but of high disruptive potential for Internet users and access rights - and potentially affecting other, perfectly legitimate activities as a collateral effect. In this paper, we will describe the unexpected and perverse effects of this law using the notion of legislative serendipity to explain why this law has never reached the target it was intended for.

\section{Introduction}

In the information society, the production, distribution and manipulation of data, content, and information represents one of the main economic, political and cultural activities (Beniger, 2009). This led to the establishment of the so-called knowledge economy, where most of the wealth is generated through the exploitation of information (Kim \& Mauborgne, 1999).

The advent of digital technologies spurred the development of new information and communication technologies that greatly facilitate the production and dissemination of content. Through the Internet, information can be easily reproduced and distributed at a global scale, in virtually no time and at virtually no costs. While this provided new opportunities for right holders -and the creative industries more generally- to explore new business models and experiment with new added-value services, the same technologies also supported the practice of copyright infringement, which has nowadays become widespread on the Internet (Tehranian, 2007).

Today, given the growing amount of piracy that is emerging online, the regulation of content production and reproduction has become an important challenge. In order to succeed, this challenge must be tackled with carefully drafted legislation that properly accounts for the specificities of the digital world (Litman, 2001). Legislators that do not properly understand the social dynamics underlying the practices they are trying to regulate will always, and necessarily, encounter significant barriers when it comes to applying the law. In the process of public policy making and legal drafting, an important number of variables (and the relationships between them) remain uncertain. The success of the law ultimately depends on its implementation, and evaluation of the law must account for what its ensuing effects are: "A law is an effort of Government and Parliament to create some order for a segment of society. Whether a law is 
effective in regulating that segment of society depends on the way that citizens use entitlements the law provides, on how administration officials exercise the authorities granted, and whether both citizens and officials comply with its rules" (Herweijer \& Winter, 1995). When the effects of the law do not reflect what the law had originally been intended for, we are in a situation of legislative serendipity (defined in Section I).

France has definitely been a pioneer on the copyright law front. Over the years, a number of legal reforms have been enacted into French legislation, although, when it came to assessing the law, the relevant criteria of evaluation (in terms of effectiveness, predictability, justice, equality, and the impact on the rules of law) were absent.

After many years of experimentation with various pieces of legislation aimed at reducing the rate of online copyright infringement (see e.g. the LCEN law ${ }^{1}$ of 2004, the DADVSI law ${ }^{2}$ of 2006, and AntiCounterfeiting law $^{3}$ of 2007), in 2009, the HADOPI law ${ }^{4}$ (presented in Section II) introduced the 'graduated response' into in French legislation with a view to discourage the use of peer-to-peer filesharing networks for the illegitimate exchange of copyrighted works. The law established a new governmental agency - the HADOPI - in charge of policing the network against copyright infringement (as described in Section II.1) and elaborated a graduated law enforcement procedure which has come to be regarded as the first implementation of the 'three-strike regime' (described in Section II.2), allowing for individuals that allegedly and repeatedly infringed copyright law to potentially be cut off the Internet. The law also introduced an obligation for Internet Services Providers (ISPs) to disclose the identity of alleged infringers (see Section II.3), along with a new administrative charge, as a complement to the charge for copyright infringement, for failure to secure one's Internet connection (Section II.4).

The HADOPI law was an attempt from the legislator at devising a new and innovative way to reduce the amount of piracy on the Internet. Today, however, the three-strike regime is regarded by many as a failure. Indeed, the graduated response did not succeed at discouraging, nor even slightly reducing the rate of copyright infringement. Instead, it is generally believed that the HADOPI law actually had a series of perverse effects (analysed in Section III) that led to a decrease, rather than an increase in the sales of digital content (Section III.1), and even diminished the opportunities for copyright enforcement by pushing users towards using more sophisticated tools or techniques (described in Section III.2) in order to escape from the draconian character of the law. Besides, the law has been accused of being both disproportionate and unconstitutional, to the extent that it was impinging upon the fundamental rights of freedom of expression and freedom of access to information, not respecting due process and reversing the presumption of innocence (Section III.3).

While the actual effects of the law are inevitably difficult to measure, in practice, it is nonetheless possible to estimate the impact that the law had on the rate of copyright infringement (e.g. by looking at its effects on the use of peer-to-peer file-sharing networks; or other types of platforms for the exchange of digital content) and balance them with the costs imposed by the law (e.g. according to its effects on privacy, anonymity, and freedom of expression).

\footnotetext{
${ }_{1}^{1}$ LOI n² 2004-575 du 21 juin 2004 pour la confiance dans l'économie numérique

${ }^{2}$ LOI n 2006-961 du 1er août 2006 relative au droit d'auteur et aux droits voisins dans la société de l'information (DADVSI)

${ }^{3}$ LOI n ${ }^{\circ} 2007-1544$ du 29 octobre 2007 de lutte contre la contrefaçon

${ }^{4}$ LOI n $2009-669$ du 12 juin 2009 favorisant la diffusion et la protection de la création sur internet
} 
Yet, in spite of its apparent incapacity to counteract copyright infringement, the real impact of the law lies in the more subtle, unintended consequences it engendered (illustrated in section IV). It is, in fact, important to assess the success of the law not only against what it was actually meant to achieve, but also, and perhaps most importantly, according to what it achieved in addition to (or beyond) what it was actually meant to. This relates, most notably, to its impact on the privacy and anonymity of users (Section IV.1), as well as on the deployment of grassroots community mesh networks in France (Section IV.2).

While they might have serious negative effect on the civil liberties and autonomy of users, most of these consequences were, however, unintended, and had not been properly accounted for by the legislator in charge of drafting the law. They are, therefore, likely to remain for the most part unnoticed when assessing the actual impact and effectivity of the law. As such, the HADOPI laws constitutes a perfect illustration of legal serendipity -defined as the emergence of unexpected side-effects in the implementation of a rational decision, be it a normative or judicial decision. Thus, after providing a general introduction to the concept of serendipity (Section I.1) and how it can be transposed into the legal field through the notion of legislative serendipity (Section I.2), the remainder of this paper will illustrate how the HADOPI law can be described as a case of negative serendipity in the legal field.

\section{Introduction to legislative serendipity}

\section{What is serendipity?}

Serendipity is the art of discovering new things by observing, and learning from unexpected situations. It can lead to the emergence of a theory, a law or perhaps simply an observation, which had never been planned and therefore not intentionally sought for (Van Andel \& Bourcier, 2012). Coined by Walpole (1754) in the tale "Travels and adventures of Three Princes of Serendip", the "serendipity pattern" has rapidly been applied to the field of science, eager to understand how people make discoveries. Yet, the ability to extract knowledge from an unexpected event covers all areas of human activity, including business, law and politics.

Serendipity comes from a propensity for exploiting the unexpected. It starts from the observation of a completely new situation, which requires a novel interpretation of a particular result. If investigation consists in the careful observation of certain facts, from which a conclusion can be drawn, serendipity emerges when these facts come to be regarded as the sign of something else. Serendipity makes it possible to draw new conclusions based on unexpected outcomes, by reassessing the results in a different manner than it had been done thus far. In the realm of science, this can be described as speculation based on observations.

Serendipity is present in all domains of human activity, although its impact has been, thus far, mostly analysed in the context of hard and/or experimental sciences. A much less investigated field of research is how serendipity affects social sciences, such as politics, law and jurisprudence. Indeed, as observed by Boudon (1991), social scientists are generally not interested in exploring the concepts of "chance" or "fortuity" because that would require them to admit that they could not anticipate the reasons why an event occurred. 
The discovery of "America" is perhaps the best example of serendipity outside of the hard sciences. Christopher Columbus, who was looking for a direct route to India, discovered the American continent instead. He found a whole new world, while he was looking for another ocean or sea. Yet, this discovery was only possible because of his creative and open-minded intellectual approach, his attempt at looking for a different means to achieve the same goal. We could derive from there that a good definition of serendipity might be: Finding something better (or different) than what we are looking for.

\section{Legislative Serendipity}

When applied to the legal field, serendipity illustrates the unintended consequences (positive or negative) that a policy or law can produce on society. This opens up epistemological and, to some extent, political questions, by bringing up the relevance of the unexpected in public policy research and practice. In this regard, a particularly interesting application of serendipity that is worth exploring is the role it plays in the context of public action, i.e. in the elaboration of public policies and the drafting of normative rules.

Public action is designed to promote good behaviours or discourage bad behaviours in a population of actors. As a general rule, governments and public administrations always plan the objectives and evaluate the impacts of public policies, before they are turned into legislation. Yet, their implementation into law might trigger many unintended consequences or even produce a series of perverse effects that could not have been readily foreseen by the policy makers themselves (Bourcier, 2011).

What we call unintended consequences (sometimes referred to as unexpected or collateral effects) is a phenomenon that looks a lot like serendipity: a voluntary social or legal intervention that might lead to a series of unexpected and non premeditated effects. The term was popularised by American sociologist R.K. Merton (1936) in a seminal article investigating a well-known phenomenon: unintended consequences as that particular set of outcomes which are different from the one intended by a purposeful social action and which might even be counterproductive to that action. They can be roughly grouped into three categories:

- Positive, unexpected benefits which generally regarded as the result of chance, luck or "pure serendipity" (e.g., the medieval policy of setting up large hunting reserves for the nobility has preserved green space throughout England and other places in Europe).

- Negative, unexpected detriments occurring in addition to, or in substitution to the desired effect of the policy, and which make the problem worse (e.g., while irrigation schemes provide people with water for agriculture, they can increase waterborne diseases that might have devastating effects on health).

- Perverse effects which are contrary to the original intention of the law (e.g. the construction of protective offshore structures in Bangladesh resulted in a much lower 
level of security overall, as people began moving closer to the shore due to a higher sense of security). ${ }^{5}$

These three types of unintended consequences can easily be observed in the legal field, by looking at the "incidence" of legal norms to a particular target. As clearly expressed by J. Carbonnier (1988), "the phenomenon of incidence is a measure of both the effectiveness and ineffectiveness of the law". When the law misses its target, it might be ineffective in one field, but highly effective in another, unexpected one (e.g. in the context of tax law, one tax that was meant to regulate the large sugar producers might ultimately affect the amateur jam makers).

This problem is related to the gap that subsists between different levels of analysis. Oftentimes, there is a mismatch between the actual and intended effects of the law, because legislators take into account only part of the system, rather than the system as a whole. In fact, the boundaries of the system are not "natural", they organically evolve according to the intended scope of the law. Some effects are "collateral" or "unintended" only because the law was reduced to a particular subset of actions, regardless of the impact it has on different types of actors or actions. If we change the level of observation, these effects automatically become part of the equation.

Yet, in the context of collective action, limited feedback or communication might lead to substantial dysfunctions. Game theory provides a good illustration of these situations where a set of rational agents are trying to find a good strategy - the best strategy - for all circumstances, regardless of the strategy of the opponent. From the point of view of each individual actors, the best strategy is the one that will maximize individual gain or utility. The perverse effects of these strategies are only visible from an outsider perspective: only by observing the relationships and interactions between all of these actors, one can understand that they would each get a better payoff by coordinating their actions.

The same can be said in the case of public policy or law making. Even if the policy makes sense and the law properly reflect such policy, after the legal provisions have been enacted, they often receive different interpretations, and possibly become subject to circumvention by specific categories of agents. As a result, the outcome of many public policies is often unexpected, and sometimes even contradictory or counterproductive. The reason is that the interactions of citizens seeking to maximize their own individual utility might produce an outcome that ultimately goes counter the overall intentions of the law. The perverse effect of the law can be seen as an

\footnotetext{
${ }^{5}$ An example might illustrate how the attempt by public authorities to protect the population against a particular risk may engender a series of unexpected and disastrous consequences that could not be foreseen by policymakers themselves. In the sixties, engineers decided to build huge offshore structures in Bangladesh to protect coastal areas from erosion, high tides and natural disasters. Unfortunately, these structures gave such a big sense of security that people started settling on the shore. When a cyclone hit on the region in 1970, millions of people perished. For more details, see Van Andel \& Bourcier (2009; p.212).
} 
aggregated result of the individual will of many individual actors that is not always in line with the collective will of society as a whole that the law was meant to regulate.

Thus, to govern is to decide in an uncertain world. The law is generally considered an efficient means to conduct governmental policy and exercise constraints on human actions. Yet, in this uncertain world, little is known about the context of future actions or the set of possible interactions between individuals. Besides, the rules laid down by the laws are orders oriented towards specific classes or categories of persons, rather than individuals themselves. They could trigger a variety of unintended effects because their application depends on the circumstances and on the multiple interpretations that can be given to a fact, a word, or an action. This means acknowledging that the regulatory bodies cannot predict in advance the actual or potential effects of every legislative intervention, since "instruments used with a view to attaining a specific goal may have other effects than anticipated" (Ten Heuvelhof \& de Bruijn, 1995; p. 173).

Legislators are thus faced with the difficult challenge to elaborate a set of rational rules and decisions that they know will produce unexpected effects as soon as they become part of the social fabric of society, i.e. as soon as they become embedded into a complex system of rules and interactions between players. These unintended effects - which Alain Anciaux (1995) defined as "serendipitous effects" - show that we all belong to a set of complex and dynamic systems, a network of ramified and reticulated systems that make it difficult to react in a preventive and consequential manner to any change in these systems ${ }^{6}$ (Van Andel \& Bourcier, 2012). Laws may come with either positive or negative consequences for the players, depending on which side one takes. They might also be voluntarily diverted by certain actors or groups of actors, so that the observed side-effects might turn out to be even worse than the original scenario. ${ }^{7}$

Research on serendipity might help shed some light not only on the act of discovery as a mental process, but also on the process of managing uncertainty as institutionalised practice. Public policies based on the attributions of consequences to actions are more likely to fail because their analysis may be distorted due to various simplifications or improper justifications. The larger is the interval of time between an action and its consequences, the greater is the chance that unexpected consequences will occur.

Various solutions have been adopted to help public authorities incorporate uncertainty into the lawmaking process. Most of them require adopting a more pragmatic approach to decisionmaking so as to better cope with uncertainty. One interesting example is, for instance, the

\footnotetext{
6 "Les "effets sérendips" montrent que nous sommes dans des systèmes complexes dynamiques c'est-à-dire des systèmes ramifiés, réticulés et qu'il est difficile d'avoir une attitude conséquentialiste 'à un coup”, in Van Andel \& Bourcier (2012; p. 255).

7 For example, most Western countries concerned by welfare policies have provided benefits guaranteeing a minimum income (revenu minimum) to people whose resources are low. These allocations have produced unexpected results (both positive and negative) that illustrate the problems encountered in the design of social aid.
} 
incorporation of sunset clauses stipulating that a particular law should cease to exist after a given period of time, or as soon as they have fulfilled their objectives (unless legislative action is taken to extend the law). Other solutions relate to the way in which public policies are elaborated and legislations are drafted. By providing public discussion forums accessible to many interested stakeholders, those who will be the most affected by the law can expose their objections on the applicability of the rules to come and their opinions as regards the possible consequences of these rules (see e.g. the public consultation for the Marco Civil in Brazil, or for the Law on the digital economy in France). Finally, the advent experimental laws, designed to promote a gradual, incremental approach to law-making, requires periodic evaluations of the effects of laws and encourage the creation of more flexible rules that can more easily adapt to technological advances.

These were, however, not the methods that prevailed in the context of the implementation of the HADOPI law, one important piece of legislation adopted in France with a view to discourage copyright infringement online. In the following sections, we will present a general overview of the HADOPI law, and we will rely on the lessons learnt from previous research in the field of serendipity in order to compare the original intentions of the law with the actual (and for the most part unintended) consequences it had on copyright infringement, as well as other legitimate activities, including the exercise of users' fundamental rights and civil liberties.

\section{General overview of the HADOPI law}

In France, the copyright regime implements a strong, but mostly ineffective system of criminal liability. Copyright infringement is regarded (just as counterfeiting) as a misdemeanor that is punishable by 3 years in prison and a fine up to 300.000 euros (see article L. 335-2 of the French Intellectual Property Code). In practice, however, charges for copyright infringement generally only results in low fines and hardly any convictions.

In particular, with the advent of Internet and digital technologies, copyright infringement has become ubiquitous in the digital world. As a result of the deployment of many different peer-to-peer networks for the sharing of digital files (e.g. Napster, Kazaa, BitTorent, etc), more and more individuals can download and upload digital media files, whose legal status is sometimes difficult to ascertain. Online piracy has thus become commonplace, and generally perceived as a legitimate activity amongst Internet users. Indeed, Internet file-sharing is for the most part done for private purposes, without any intentions of commercial gains. It is thus difficult to prove the malicious intent of individual infringers - an essential requirement for criminal liability. ${ }^{8}$ This, in addition to the complexity of quantifying the damages caused by online piracy (Fisk, 2009; Barker, 2004; Boorstin, 2004), is such that imposing criminal liability for non-commercial file-sharing is generally considered to be neither fair, nor proportional to the actual damages incurred by the right holders.

\footnotetext{
${ }^{8}$ In criminal law, intention is generally regarded as necessary element to constitute a crime. Except in the case of strict liability crimes, criminal liability cannot be imposed to a person who acted without intent.
} 
French Law n 2009-669 "Creation et Internet"9 for the promotion and protection of creative works (socalled HADOPI law) was introduced on June $12^{\text {th }} 2009$ with a view to encourage compliance with copyright law. It was immediately followed by Law $n^{\circ} 2009-1311$ on the criminal protection of creative works on the Internet ${ }^{10}$ (HADOPI II law), introduced on October $28^{\text {th }} 2009$ to address some of the constitutionality concerns of the former law. Together, these two laws (along with a series of over 10 law decrees) establish a new regulatory framework which represents an attempt by the French government to counteract the inexorable rise of online copyright infringement by means of an innovative legislative solution known as the "graduated response" (riposte graduée, in French). The most relevant components of these laws relate to the establishment of (1) a new governmental agency in charge of promoting the distribution and protection of creative works on the Internet; (2) a 'three-strike regime' for online copyright violations and illegal file-sharing; (3) an obligation for Internet Service Providers (ISP) to disclose information about their subscribers; and (4) a tort of 'gross negligence' for failure to secure one's Internet connection.

\section{A new governmental agency: HADOPI}

The law establishes the Haute Autorité pour la Diffusion des œuvres et la Protection des droits d'auteur sur Internet (HADOPI), a governmental agency responsible for promoting the distribution and protection of creative works on the internet. Intended to replace the former Regulation of Technical Measures Authority created by the DADVSI law, ${ }^{11}$ this new governmental agency has been vested with the mandate to police the Internet against copyright infringement, as well as to ensure that Internet subscribers secure their connections to prevent the unauthorised redistribution of copyrighted material.

Specifically, the HADOPI is composed of one College and one Commission for the Protection of Rights. The functions of the College are defined within Article L.331-13 of the French Intellectual Property Code (IPC) and consist inter alia of monitoring both the legitimate and illegitimate uses of copyrighted works, protecting creative works against potential copyright violation on the Internet, and regulating the use technical measures for the protection of these works. The Commission is in charge of notifying right holders of the unauthorised dissemination of their work online, and to enforce the sanctions provided for under the HADOPI law. Article L.331-21 also grants the Commission the powers to investigate potential copyright violations, and - if necessary to do so - to request relevant ISP to disclose some of the information necessary to bring the investigation to an end.

\section{Procedural rules regulating the three-strike regime}

In order to counteract the growing amount of piracy in the digital world, the HADOPI law also introduced an additional system of penalties, applicable whenever an infringing act has been committed over an Internet connection. This new system of penalties - which came to complement the standard provisions of copyright law - take the form of a three-strike regime consisting of two preliminary operations (notifications and warnings) and one final repressive action involving fines and a potential suspension of Internet access.

\footnotetext{
${ }^{9}$ LOI n ${ }^{\circ}$ 2009-669 du 12 juin 2009 favorisant la diffusion et la protection de la création sur internet.

${ }^{10}$ LOI n $^{\circ} 2009-1311$ du 28 octobre 2009 relative à la protection pénale de la propriété littéraire et artistique sur internet.

${ }^{11}$ LOI n ${ }^{\circ}$ 2006-961 du 1 août 2006 relative au droit d'auteur et aux droits voisins dans la société de l'information
} 
Specifically, Articles L.331-17 and L.331-25 of the Intellectual Property Code stipulates that, upon receiving a claim for copyright infringement from the relevant right holders or their representatives (e.g. collecting societies), the HADOPI will initiate a 'three-strike' procedure which can be summarized in the following steps:

1. A first warning (avertissement) is communicated via e-mail to the subscriber of the ISP, whose identity has been derived from IP address identified as the source of the alleged infringement. The warning notifies the subscriber of the alleged copyright violation and reiterate the obligation to secure the Internet connection, as provided for under the law (see Article L. 336-3 of the IPC). According to Decree $n^{\circ} 2010-236^{12}$ of March $5^{\text {th }} 2010$, the warning must also provides the necessary information for the subscriber to requests further clarifications concerning the charges that he or she is being accused of, along with an overview of the possible penalties that might ensue from future or repeated infractions (see Articles L.335-7 and L.335-7-1 of the IPC).

2. If, within the period of six months after the first warning, the same subscriber is identified as the source of another infringing act, a second e-mail warning is sent to the subscriber, along with a certified letter with acknowledgement of receipt (or any other means capable of proving the actual reception of such warning by the subscriber) containing similar content to the former notification. The subscriber has the opportunity to respond during a period of 15 days after receiving the letter, in order to provide justifications for the repeated infringement.

3. If, within the period of one year after the second warning, the same subscriber is - once again identified as the source of an infringing act, the HADOPI is entitled to start a procedure against that subscriber, which might result in a fine and, possibly, a temporary suspension of the Internet connection, along the interdiction to subscribe to any other ISP over a period of time ranging from 3 months to one year. In this last phase, the subscriber is entitled, if he so wishes, to challenge the decision taken by the HADOPI in front of a judge, by showing that he or she was not responsible for the alleged infringement, and that necessary measures had been taken to secure the Internet connection (the burden of proof is, of course, on the appellant). Alternatively, the subscriber might chose to negotiate for a reduced suspension's period (between 1 and 3 months) by admitting to have personally committed the infringing act and committing not to further engage into similar activities in the near future.

The constitutionality of such solution has rapidly been challenged on the grounds that the law did not comply with the presumption of innocence and separation of powers, that it infringed upon the rights of defense, fair trial, and the right to be heard, and that the sanctions were anyways disproportionate to the tort to the extent that they constituted a potential violation of fundamental rights (Lucchi, 2011). On may 20th 2009, deputies from the Socialist, Communist and Green parties initiated an appeal to the Constitutional Court to deliberate on the constitutionality of the HADOPI law. ${ }^{13}$ On June $10^{\text {th }} 2009$, the

\footnotetext{
12 Décret n ${ }^{\circ}$ 2010-236 du 5 mars 2010 relatif au traitement automatisé de données à caractère personnel autorisé par l'article L. 331-29 du code de la propriété intellectuelle dénommé « Système de gestion des mesures pour la protection des œuvres sur internet »

${ }^{13}$ The constitutionality of the law was challenged on eleven different points, and it was thus requested that the law be either revoked or amended. For a more detailled overview, see http://www.ecrans.fr/IMG/pdf/recourshadopi.pdf
} 
French Constitutional Court declared that the procedural rules establishing the three-strike regime were unconstitutional because incompatible with the French 1789 Declaration of the Rights of Man and of the Citizen. ${ }^{14}$ Indeed, it was held by the Court that, given the key role that the Internet plays in today's information society, the right to freedom of expression naturally implies the right to access to the Internet. Since the latter is not an absolute right, disconnection is allowed. Yet, to the extent that cutting off someone's access to the Internet might impinge upon the right to freedom expression, such a decision could not taken a mere administrative body. Only a judicial procedure could impose a temporary suspension of the Internet connection, whose overall duration should be proportionate to the tort.

The HADOPI law has thus been amended by Law $n^{\circ} 2009-1311$ on the criminal protection of creative works on the Internet ${ }^{15}$ (so-called HADOPI II law) to include judicial review before suspending one's Internet connection. Yet, in the revised version of the law, Article L.335-7-2 of the IPC stipulates that the HADOPI is nonetheless entitled to rely on a simplified procedure to obtain a court order from a single judge trial (the same procedure used to deal with parking or speeding tickets). The judge is in charge of deliberating on whether to suspend the Internet connection (and for how long), as well as establishing the overall amount of the fine. It is worth mentioning that a decision from the judge to revoke a subscriber's access to the Internet does not necessarily entail a termination of the contract -- i.e. the subscriber might still have to pay for the Internet connection, even if he or she cannot access it anymore.

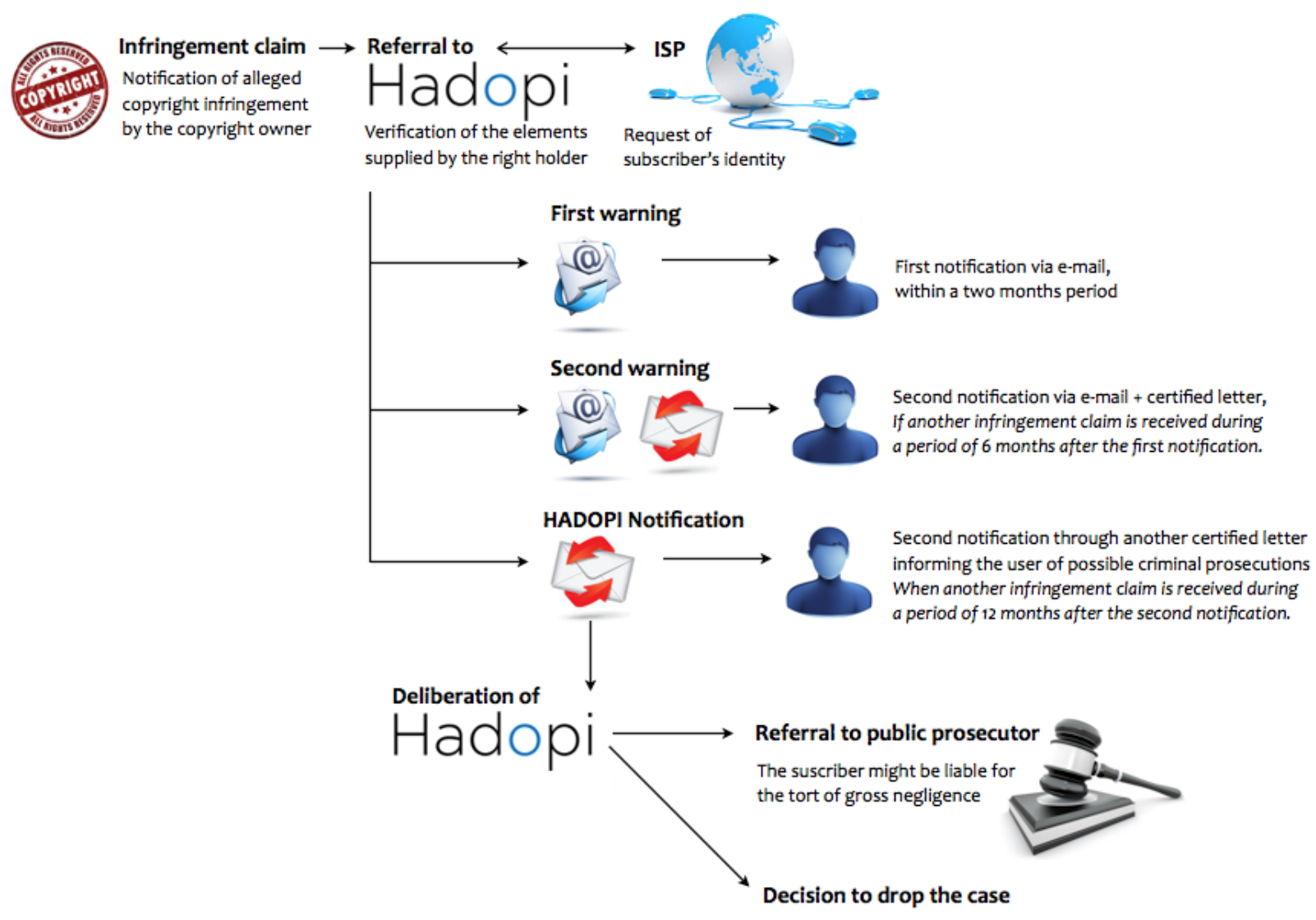

14 Décision $\mathrm{n}^{\circ}$ 2009-580 DC du 10 juin 2009 du Conseil Constitutionnel

${ }^{15}$ LOI n $^{\circ} 2009-1311$ du 28 octobre 2009 relative à la protection pénale de la propriété littéraire et artistique sur internet. 
Figure 1: Overview of the procedural steps of the three-strike regime under the HADOPI law Source: http://i.i.cbsi.com/cnwk.1d/i/tim2/2013/07/10/Schema Reponse Graduee 0.png

\section{Obligation to disclose subscriber's personal data}

Decree $n^{\circ} 2010-872^{16}$ of July $26^{\text {th }} 2010$ modifies article L.331-27 of the French Intellectual Property Code, which now stipulates that, whenever a particular IP address has been identified as the source of copyright infringement, the ISP is under the obligation to disclose the personal information (i.e. identity, address, telephone number and email contact) of the subscriber to which such IP address was assigned, under the simple request of the HADOPI. This is in contrast to the standard procedure for counterfeited goods which requires a judicial order from the court (i.e. a warrant). The law also stipulates that failure for the ISP to disclose such information constitutes a $5^{\text {th }}$ order infraction, which is subject to a fine up to 1500 euros.

An important issue is, however, that it is not possible to rely only on the IP address to determine who is actually responsible (and should therefore be held liable) for an infringing act. Indeed, an IP address cannot be directly linked to an individual, nor even to a particular machine. Most ISP are offering Internet connection where a single IP is used in common by several users. Besides, WiFi connections are often shared among different persons, whose identities are not necessarily the same as those who subscribed for the Internet connection. Thus, it is easy for any alleged infringer to escape from liability by simply claiming that someone else was using the same Internet connection.

\section{Gross negligence for insecure Internet connection}

A potential solution to that problem has been proposed by Decree $n^{\circ} 2010-695^{17}$ of June 25 th, 2010, which introduces a tort of "gross negligence" (négligeance caractérisée, in French) concerned not with copyright infringement per se, but with the improper securitisation of the Internet connection.

A similar tort had already been introduced in 2007 through the DADVSI law (transposing the European Copyright Directive into French legislation), which required effective securitisation of the Internet connection to prevent the exchange of copyright material without prior agreement from the right holders (see article L. 335-12 of the French Intellectual Property Code). Yet, under the DADVSI law, although subscriber were responsible for the use made of their Internet connection, there were no specific sanctions in place for the mere unauthorized usage thereof.

Decree $\mathrm{n}^{\circ}$ 2010-695 amends the Intellectual Property Code by introducing a new article (L. 336-3) which stipulates that "the subscriber to an Internet connection is under the obligation to ensure that such connection will not be used for the reproduction, representation, or making available of works protected by copyright or neighboring rights without the permission of the right holders, as specified within the books I and II of the same Code." 18 According to the Decree, in the absence of "legitimate motives" not to secure the Internet connection, liability for gross negligence might arise either from (a) the failed

\footnotetext{
${ }^{16}$ Décret $\mathrm{n}^{\circ} 2010-872$ du 26 juillet 2010 relatif à la procédure devant la commission de protection des droits de la Haute Autorité pour la diffusion des œuvres et la protection des droits sur internet

${ }^{17}$ Décret $\mathrm{n}^{\circ}$ 2010-695 du 25 juin 2010 instituant une contravention de négligence caractérisée protégeant la propriété littéraire et artistique sur internet

${ }^{18}$ Article 11 of the HADOPI law, incorporated as Art. L. 336-3 within the French Intellectual Property Code.
} 
attempt by subscribers to set up effective security measures aimed at precluding unauthorized access to their Internet connection, or (b) the lack of diligence in the implementation thereof.

The tort of gross negligence is defined as a $5^{\text {th }}$ order infraction, which might lead to a fine up to 1500 euros, along with a potential suspension of the Internet connection for a maximum period of one month. The tort does not, however, constitutes a general obligation to secure the Internet connection. Liability might only arise after the third strike, after the subscriber has already been warned twice that his or her IP address had been found as the source of infringing activities, and still has not attempted to secure the Internet connection. Yet, the law does not precisely stipulates the measures that need to be undertaken in order to secure an Internet connection. Hence, while they might have taken the appropriate steps to secure their connection (e.g. by protecting their wifi connection with a password and/or by installing software specifically intended to prevent the downloading of copyright infringing material), were their Internet connection to be identified as the source of an infringement, the subscribers claiming not to be the authors of the alleged infringement might nonetheless be held liable for gross negligence, to the extent that they did not effectively secure their Internet connection.

It is important to note that the tort of gross negligence for the improper securitisation of the Internet connection is neither a precondition, nor a necessary consequence to a claim of copyright infringement. It merely constitutes an additional (complementary) course of action for right holders eager to dissuade users from infringing the copyright in their works - which does not prevent them from also issuing a claim against copyright infringement, if they so wish. Indeed, this tort does not constitutes an alternative to a claim for copyright infringement, but rather comes to complement this claim. Any individual whose Internet connection has been used for the purposes of copyright infringement remains, in fact, potentially liable for any civil and criminal penalties provided for under the law (see Article L. 335-2 of the French Intellectual Property Code).

The introduction of such a tort constitutes perhaps a more effective mechanism against the practices of copyright infringement that have nowadays become pervasive on the Internet. It seems, indeed, more appropriate to counteract the rise of online piracy through an administrative sanction, rather than relying on (highly unpopular) criminal penalties, involving heavy fines and potentially even jail time. Yet, such a legislative solution might engender a series of perverse and unintended consequences that have not been properly accounted for by the law.

\section{Perverse effects of the HADOPI law}

As a measure to counteract the growing popularity of illegal file-sharing, the HADOPI law might ultimately deprive the creative industries of at least a portion of their customers, but also encourage the use of more sophisticated techniques for the exchange of digital files, which have actually not been accounted for under the law. Most importantly, the introduction of a tort of gross negligence for failure to secure the Internet connection might end up reversing the presumption of innocence, as the subscriber of an Internet connection whose IP address has been identified as the source of an infringing act will be held liable for a secondary infraction, unless he or she can prove all necessary steps had been taken to secure the Internet connection. 


\section{Effect on sales}

The three-strike regime has been enacted with a view to promote the economic interests of copyright owners, by deterring the use of peer-to-peer networks for the unauthorised exchange of copyright files. The effectiveness of these measures on reducing online piracy, and the impact they had on the sales of cultural content are, however, open to debate.

In 2012, the HADOPI issued a report ${ }^{19}$ showing that, after the promulgation of the law, there had been a substantial decrease in the usage of peer-to-peer file-sharing networks (which went from 4.5 millions users in 2010 to 3 millions users in 2011). Shortly after, the International Federation of the Phonographic Industry (IFPI) representing the recording industry worldwide argued, in its 2012 Digital Music Report, ${ }^{20}$ that the sales of digital music in France had been subject to a steady increase ever since spring 2009 (when the law was still being debated in the National Assembly). Subsequently, a study by Danaher \& al. (2012) analysed the effects of the HADOPI law with regard to a few control groups (in the UK, Italy, Spain, Germany and Belgium) and concluded that the law significantly contributed to boosting the sales of the iTunes online music store in the French territory (with an estimate of over 13 million euros of increased revenues). Yet, most of the data used to substantiate these studies is taken from before HADOPI's actual implementation into law. This, together with the bias inherent to the creative industries, which have often been accused of lobbying for stronger anti-piracy regulations by producing and promoting distorted statistics $^{21}$ (Lessig, 2004; Lev-Aretz, 2013; Dobusch \& Schüßler, 2014) is such that the accuracy of these claims is, to a large extent, questionable.

Indeed, studies from academia and civil society have come to an entirely different conclusion. ${ }^{22}$ Several studies concluded that the HADOPI law had no substantial deterrent effect on copyright infringement (Dejean \& al., 2010; Arnold \& al., 2014). Others showed that the three-strike regime introduced by the HADOPI law might actually have a negative impact on the market for digital content (Huygen \& al. 2009; Poort \& Rutten, 2010), since 'digital pirates' are often also the main purchasers of digital content on the Internet (Peukert \& al., 2013). The HADOPI itself admitted ${ }^{23}$ that those who download the most content online are also those who purchase the most digital content from the cultural industries. In this regard, a study ${ }^{24}$ by the University of Rennes found that, while only $17 \%$ of those who do not engage in copyright infringement practices online actually purchase digital content, $47 \%$ of those who rely on filesharing for the exchange of digital files are also likely to purchase digital music or videos, whenever they

\footnotetext{
${ }^{19}$ See the HADOPI Report: "Hadopi, 1 an $1 / 2$ après son Lancement" from 2012, available at http://www.hadopi.fr/sites/default/files/page/pdf/note17.pdf

${ }^{20}$ See IFPI Digital Music Report of 2012, available at http://www.promusicae.es/documents/viewfile/86-ifpidigital-music-report-2010

${ }^{21}$ This was particularly visible during SOPA, PIPA and ACTA campaigns, where the creative industries extensively relied on biased data and statistics to substantiate their claims for the need of stronger Intellectual Property protection. See e.g. Lev-Aretz (2012).

${ }^{22}$ For a comprehensive overview of these studies, see https://wiki.laquadrature.net/Studies_on_file_sharing

${ }^{23}$ See the HADOPI Report: "Hadopi, biens culturels et usages d'internet: pratiques et perceptions des internautes français", p.45

${ }^{24}$ The study is based on a sample of 2000 individuals from the Brittany region which have been subject to a telephone survey during a period of 3 months after the promulgation of the law HADOPI II. For more information, see Dejean \& al. (2010).
} 
find something they like. Even better, according to a study ${ }^{25}$ undertaken by the Prospective Technological Studies of the European Commission's Joint Research Center, most of the music that is consumed legally by the surveyed individuals would not have been purchased if they had not had access to illegal means for downloading that content. Accordingly, cutting people off the Internet because of the unauthorized exchange of copyrighted works on peer-to-peer file-sharing networks could potentially jeopardize a substantial part of the market for cultural content, and consequently eliminate a considerable source of income for right holders.

\section{Effects on copyright infringement}

With the HADOPI law, the French legislature tried to fight online piracy by implementing harsher laws against copyright infringement. Yet, by focusing on only one particular type of copyright infringement the one achieved through the use of peer-to-peer file-sharing networks - the law might actually promote the very same practices that it was actually meant to deter users from.

In a 2010 study $^{26}$ from the University of Rennes analysing the impact of the three-strike regime on the behavior of Internet users, it was shown that the law had no substantial deterrent effect on file-sharing. Conversely, it was found that piracy actually increased of about 3\% after the promulgation of the HADOPI law (Dejean \& al., 2010). According to the study, two thirds of those who declared having given up on file-sharing as a result of the new sanctions introduced by the law, also admitted to have been exploring alternatives ways of getting copyrighted material online. Thus, while the number of users connected to peer-to-peer file-sharing networks has dropped (of 15\%), there has been a notable increase (of 27\%) in the use of alternative platforms or tools for copyright infringement which have not been properly contemplated under the law. This is the case, for instance, of direct download websites (such as Rapidshare, Megaupload, etc) and illegitimate streaming platforms (such as Allostreaming), but also legitimate platforms (such as Vimeo, Youtube or DailyMotion) whose content can be illegitimately download by means of specific applications (such as Streamget, Clickster, etc). Alternatives mechanisms are also acquiring more and more popularity, such as encryption tools, proxies, VPNs or anonymous relay networks (such as Tor) that make it difficult - if not impossible - for right holders to identify the content and/or the source of online communications.

Figure 2: Evolution of the sources of copyright infringement before and after HADOPI. Source: Dejean \& al., (2010). Available at http://www.marsouin.org/IMG/pdf/NoteHadopix.pdf

\footnotetext{
25 See the Institute for Prospective Technological Studies' report: Digital Music Consumption on the Internet: Evidence from Clickstream Data, April 2013. Available at http://www.scribd.com/doc/131005609/JRC79605

${ }^{26}$ See footnote 22 , Ibid.
} 


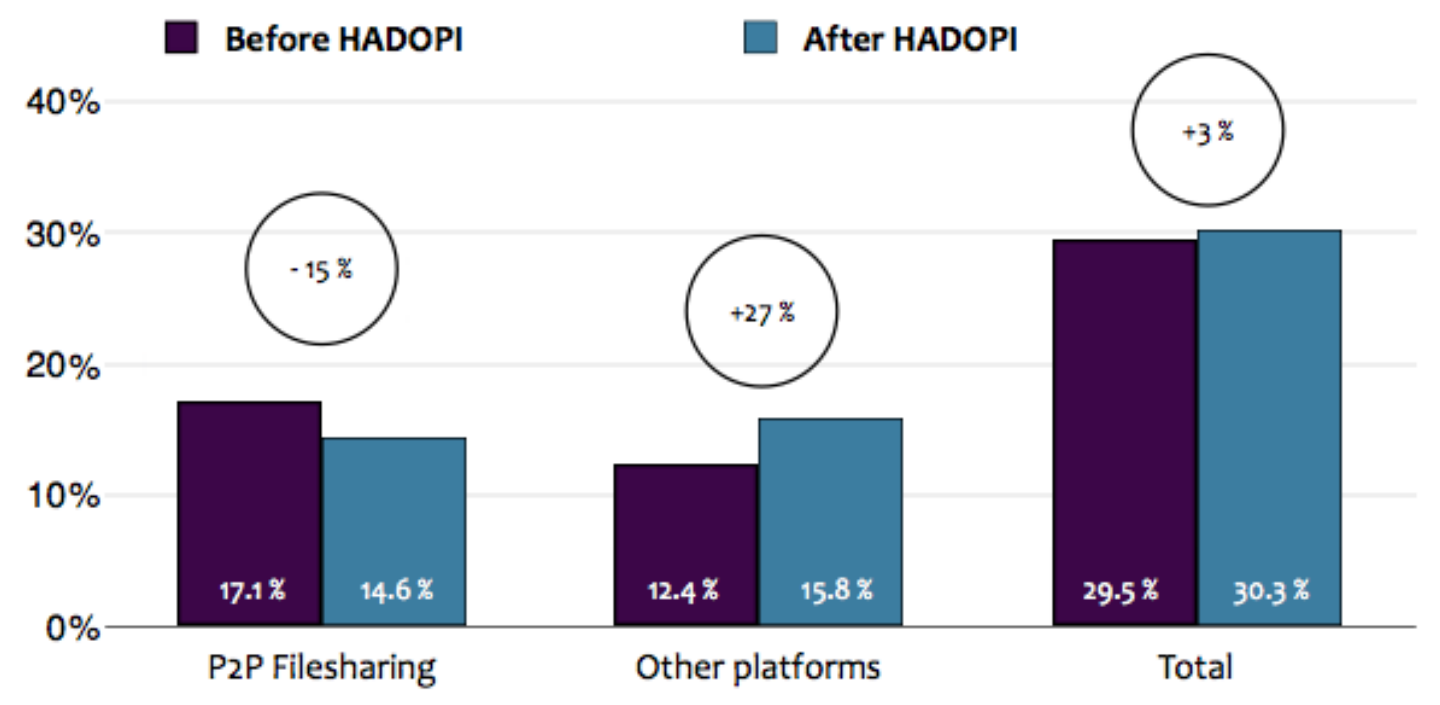

Overall, it appears that the increased usage of alternative tools for the exchange of digital files more than compensates for the reduction in the use of file-sharing networks (see Fig. 2). Individuals who are better informed about the risks of file-sharing have simply shifted away from monitored peer-to-peer networks towards other, unmonitored channels allowing for the illegal downloading of copyrighted content without any fear of retaliation (Arnold \& al., 2014). Paradoxically, the draconian regime established by the HADOPI law might thus have supported online piracy, by promoting the use of alternatives platforms that were, until then, for the most part unknown to the public.

What's more, by pushing users away from traditional peer-to-peer file-sharing platforms, the HADOPI law actually contributed to the widespread adoption of encryption tools and anonymization technologies amongst standard Internet users. While this is not problematic as such, the widespread use of these technologies might have a negative effect on law enforcement, by making it harder for public authorities to fight not only against copyright infringement, but also against other types of criminal activities, such cybercriminality and terrorism.

\section{Effects on the presumption of innocence: "guilty until proven guilty"}

Perhaps one of the most perverse effects of the HADOPI law is its impact on due process and on the presumption of innocence. Article 9 of the 1789 Declaration of the Rights of Man and the Citizen stipulates that "every man is presumed innocent until proven guilty". Yet, in the first version of the law, a mere administrative agency (the HADOPI) was entitled to decide on whether (and for how long) to disconnect an alleged infringer without passing through a judicial procedure. Although the subscriber always had the chance to appeal against the decision of the HADOPI, the constitutionality of the law had immediately been challenged on the grounds that it was reversing the burden of proof: instead of the HADOPI having to show that the subscriber was guilty of copyright infringement, it was for the subscriber to prove that, in spite of his or her due diligence, someone had managed to hack into the 
Internet connection. The law was eventually struck down by the Constitutional Court, ${ }^{27}$ and replaced shortly afterwards by an amended version (HADOPI II), according to which only a decision by the criminal court could result into an actual suspension of a subscriber's Internet connection.

But even in its amended version, the HADOPI law is not devoid of any perverse effects. The law maintains, indeed, the distinction between online copyright infringement (which is regarded as a misdemeanor, punished with a considerable fine and a potential suspension of the Internet connection for up to one year) and the tort of gross negligence for failure to monitor one's Internet connection (which is regarded as a petty offense, the maximum punishment for which is a only small fine and a shorter term of suspension).

This distinction is useful to the extent that it creates new avenues for prosecution. Rights holders eager to enforce the law over alleged infringers now have a new option: either they sue them for copyright infringement, or they go after the breach of duty to monitor the Internet connection -- or both.

Yet, such distinction might be difficult to put into practice, since both charges relate to the same underlying offense: copyright infringement. Thus, although the two offenses are kept separate under the law, the provisions of the law does not properly distinguish between a criminal offender (driven by malicious intentions) and a petty offender (with no criminal intentions) that simply did not exercise due diligence when securing his on her Internet connection. What's more, the law does not even precisely stipulates what constitutes a secure Internet connection; subscribers are not told how to secure their connection, nor which tools they should install in order to escape for potential liability for gross negligence.

Hence, regardless of the efforts which have been undertaken to secure the connection, it is always possible for a third party to hack into someone's Internet connection view a view to commit an infringing act without incurring liability from it. And yet the tort of gross negligence makes it really hard for the subscriber of such Internet connection to disclaim responsibility from it. Regardless of whether the subscriber did, in fact, contribute to the infringing act, he or she will nonetheless be held liable for failure to properly secure the Internet connection. Paradoxically, the mere fact of denying responsibility for copyright infringement (despite the IP address having been detected as the source of the infringing act) can be used as a means to prove that the obligation to secure the Internet connection has not been respected -- which in itself constitutes an infraction.

From a legal perspective, this is problematic in at least two ways. On the one hand, this goes counter the doctrine of vicarious liability, according to which a judge might only impose responsibility upon one person for the failure of another, with whom the former has a special relationship. ${ }^{28}$ On the other hand, this might also go counter the presumption of innocence, by moving away from the principle of "innocent until proven guilty" towards the more controversial principle of "guilty until proven guilty" -- i.e. the subscriber is trapped in between two provisions: if he or she claims not to be responsible for the infringing act (which was therefore due to a third party hacking into the Internet connection), the subscriber might then be held liable of gross negligence for failure to secure such connection.

\footnotetext{
${ }^{27}$ Décision n ${ }^{\circ} 2009-580$ DC du 10 juin 2009 du Conseil Constitutionnel

${ }^{28}$ The doctrine of vicarious liability is common law doctrine that renders one person liable for the torts committed by another person. The classic example is that of employer and employee: the employer is rendered strictly liable for the torts of his employees, provided that they are committed in the course of the tortfeasor's employment. In such circumstances, liability is imposed on the employer, not because of his own wrongful act, but due to his relationship with the tortfeasor (Giliker, 2010). Other common situations in which vicarious liability might apply include parental relationship, or the relationship between a principal and an agent.
} 
The introduction of the tort for gross negligence constitutes, in fact, an ingenious trick to the extent that it makes it possible to incriminate alleged infringers by holding them liable for a smaller, administrative infraction, without having to go through the long and arduous procedure of criminal proceedings. Of course, as opposed to copyright infringement which might involve criminal sanctions, failure to secure the Internet connection might only result into a few administrative sanctions - which are generally much less severe, but also not subject to the same legal safeguards as their criminal counterpart (in terms of e.g. procedure and formalities, intentionality, burden of proof, etc). Although necessarily rooted into an action for copyright infringement, the tort of gross negligence constitutes, in fact, a civil infraction which can be resolved through the much easier and more expedite procedure of civil proceedings.

In this regard, it might be worth questioning the constitutionality of this regime. Indeed, while the first version of the HADOPI law has been struck down on the ground that it was constitutionally unsound, it could be argued that the revised version of the same law (HADOPI II) contemplates similar - albeit more hidden - elements of unconstitutionality. Since one cannot rely exclusively on the IP address which constitutes the source of an infringing act in order to determine the identity of the infringer, it is extremely difficult for anyone to prove who should, indeed, be held responsible for copyright infringement. And yet, the legislator has found an ingenious way to bypass the issue, through the introduction of a tort for failure to secure one's Internet connection -- thereby allowing for public authorities to incriminate subscribers who had not (yet) been 'proven guilty' under an secondary administrative tort, without having to prove neither intentionality nor damages.

\section{Unintended effects of the HADOPI law}

The HADOPI law was introduced as a legislative measure to discourage online piracy and file-sharing through a system of 'graduated response'. In practice, however, the law has been fairly incapable of achieving that objective. As previously illustrated, the law did not actually succeed in counteracting the constant rise of online piracy, nor did it succeed in discouraging the use of peer-to-peer file-sharing networks, which are still widespread on the Internet. ${ }^{29}$

In its first Activity Report, ${ }^{30}$ released 18 months after the graduated response was introduced into legislation, the HADOPI disclosed that, thus far, no one had been subject to any sanction or fine. Yet, the governmental agency has been receiving an average of 70.000 complaints per day, for a total of over 18 million IP addresses reported as the source of potential infringements since october 2010. Only 1 million of them have been communicated to the corresponding ISPs so as to obtain the identity of their subscribers. During these first 18 months, the HADOPI issued a first round of warnings to over 47.000

\footnotetext{
${ }^{29}$ Tru Optik recently released statistics estimating that every month more media content is downloaded by file sharers than are sold on iTunes, Google Play and Amazon combined. The US accounts for $10.57 \%$ of all global P2P users. As of March 2014, 31.7 million unique IP addresses were engaged in file sharing, up from a monthly average of 28.2 million in 2010. More information available at truoptik.com ${ }^{30}$ HADOPI, Rapport d'Activité 2010, available at: http://www.hadopi.fr/sites/default/files/page/pdf/rapportd-activite-hadopi.pdf
} 
subscribers, only 20.000 of which also received a second warning. The number of cases that could lead to actual prosecution for the third strike were in the number of ten, each of which need to be deliberated individually by the HADOPI. Overall, since the creation of the HADOPI in 2009, only one individual has effectively been convicted to having his Internet connection suspended for a period of 15 days, along with a fine of 600 euros. ${ }^{31}$ The injunction has, however, never been enforced, as the law had since then been reformed to remove the possibility for the HADOPI to cut off a subscriber's Internet connection. ${ }^{32}$

But while it failed in the fight against online piracy, the introduction and current implementation of the three-strike regime might still have serious implications on users' fundamental rights, such as the right to privacy and anonymity. Besides, the additional penalties introduced by the HADOPI law (and, in particular, those related to the tort of gross negligence for failure to secure one's Internet connection) could give rise to a series of unintended consequences that might negatively affect different sectors of activities, which are beyond the original scope of the law.

The issue is closely related to the question of establishing the 'target' of the law - i.e. what types of activities was the law meant to regulate, and who are the actors that should ultimately be affected by the law. The three-strike regime was specifically designed to regulate only one particular type of misbehavior, i.e. copyright infringement. Yet, if we look at the consequences it had in practice, the HADOPI law seems to have missed the 'target' given that it only had a marginal impact on reducing online piracy. Conversely, the law might have unintentionally hit a different target, insofar as it might impose a series of restrictions or limitations on different fields of endeavor, including legitimate activities - such as, most notably, the deployment of community mesh networks - which had never been contemplated by the legislator.

\section{Privacy \& Anonymity}

Important critics have been raised against the three-strike regime, and its negative implications on the privacy of Internet users. According to many, ${ }^{33}$ an improper implementation of the graduated response might lead to a situation of generalized surveillance that would necessarily impinge upon the privacy of Internet users, regardless of whether or not they have been involved into an allegedly infringing activity. In this regard, according to the French Data Protection Authority (CNIL), the law did not establish a proper balance between the need to protect the intellectual property of copyright owners, and the potential harm to the privacy of end-users that the three-strike regime might entail. ${ }^{34}$

Indeed, in order to be able to prosecute copyright infringers, the HADOPI needs to obtain information as regards the identity of these infringers. Hence, Internet communications - and in particular those taking place over peer-to-peer file-sharing networks - are increasingly being monitored by public (and private)

\footnotetext{
${ }^{31}$ In June 2013, for the first time in France, an individual was sentenced to having his internet connection temporarily cut off for an overall duration of 15 days by the Tribunal d'instance de Seine-Saint-Denis, for having downloaded illegal content despite the multiple warning letters sent by the HADOPI.

${ }^{32}$ Décret $n^{\circ} 2013-596$ du 8 juillet 2013 supprimant la peine contraventionnelle complémentaire de suspension de l'accès à un service de communication au public en ligne et relatif aux modalités de transmission des informations prévue à l'article L. 331-21 du code de la propriété intellectuelle

${ }^{33}$ Proponents of this view include several civil society organisations, such as April, Aful, La Quadrature $\mathrm{Du}$ Net, or the consumer protection association UFC Que Choisir.

34 Délibération $n^{\circ} 2008-101$ du 29 avril 2008 portant avis sur le projet de loi relatif à la Haute Autorité pour la diffusion des œuvres et la protection des droits sur internet
} 
authorities, with a view to identify the source of infringement. Yet, if monitoring the network is necessary for enforcing copyright law, is the threat of copyright infringement sufficiently high to justify the establishment of a system of generalized surveillance that might actually discourage the usage of peer-topeer communication networks, even when those are employed for perfectly legitimate purposes? Besides, the question remains as to who should be in charge of monitoring the traffic transiting through these networks, and what is the level of surveillance that can be legitimately undertaken without impinging upon users civil liberties and fundamental rights?

In France, Trident Media Guard (TMG) ${ }^{35}$ - a company specialized in monitoring the traffic of peer-topeer file-sharing networks - has been designed as the entity in charge of identifying all IP addresses which constitute the source of an infringing act on the Internet, and reporting them to the HADOPI for further processing by the ISP. TMG has since them been collecting data and metadata concerning the exchange of files on multiple peer-to-peer file-sharing networks, producing a massive collection of IP addresses with a view to identify potential copyright infringers. As a result, the company has been awarded the 2010 "Internet Orwell prize" during the French Big Brother Awards, ${ }^{36}$ on the grounds that its activities significantly undermined users' fundamental right to privacy. The harm is not only theoretical, since, in 2011, a security breach was discovered on TMG's servers, which accidentally opened a portion of its database, resulting in the unauthorised disclosure of thousands of personal data records.

In addition to the negative impact it has on the fundamental right to privacy, the current implementation of the graduated response might also severely affect the ability for users to connect to the Internet anonymously. Today, many public spaces (such as cafes, restaurants, hotels, airports, libraries, universities or parks) provide Internet connectivity by opening their network to the public at large, often without requiring any kind of subscription or registration. By making these intermediaries liable for any potential misuse of their Internet connection for the purposes of copyright infringement, the HADOPI law might either dissuade them from providing free Internet access, or require them to install specific technical means to establish the identity of users and/or prevent unauthorized access to copyrighted works. At the individual level, by introducing a tort of gross negligence for failure to secure one's Internet connection, it becomes increasingly unlikely that the actual subscribers to an Internet connection enable others to connect freely (and anonymously) to their own network. The result is a negative externality characterized by a potential reduction in Internet accessibility and a definitive impairment to users' privacy and anonymity - an unintended consequence that does not reflect the original intention of the law.

\section{Community mesh networks}

If go further into the analysis, we might notice that the HADOPI law could give rise to other unintended consequences (or externalities) that were not properly contemplated by the legislators.

\footnotetext{
${ }^{35}$ TMG works with TV broadcasters, Sports right holders, Film producers and distributors, and Music publishers to manage, protect and analyze live and recorded content on internet and TV. More information is available on their website http://www.tmg.eu

${ }^{36}$ The Big Brother Awards recognize "the government and private sector organizations [...] which have done the most to threaten personal privacy". The contest is organized in many countries by local NGOs and the awards are intended to draw public attention to privacy issues and related trends in society, especially in data privacy. More information at http://www.bigbrotherawards.org/
} 
Externalities are widespread in the legal realm. These can be either positive or negative - see e.g. the impact on freedom of expression caused by a variety of laws preventing libel or hate speech (Mayton, 1984; Massaro, 1990; Stefancic \& Delgado, 1992); the establishment of a de facto access right stemming from the legal protection granted to technical measures of protection under copyright law (Heide, 2000; Ginsburg, 2002), or simply the harm to individual privacy resulting from regulations intended to preserve public order and national security (Mell, 2002; Arnbak \& Goldberg, 2014). While people generally rejoice at positive externalities, negative externalities often remain unnoticed for a long time, until they become so widespread that they become an actual constitutive part of the ecosystem and can no longer be distinguished from the whole.

Thus, in order to fully understand the impact of the French HADOPI law, it also needs to be assessed not only with regards to the consequences it might have on copyright infringement, privacy or anonymity, but also on the likelihood of users sharing their Internet connection to the public at large. This is especially relevant in the context of community mesh networks, where the proper functioning and operation of the network depends, for the most part, on getting a sufficiently high number of individuals making their Internet connection available to third parties.

In a nutshell, community mesh networks are decentralized network infrastructures that rely on the resources provided by a distributed and loosely coordinated network of peers to provide connectivity to a particular community of peers (Zhang \& al., 2006). These networks are operated by the community and for the community. They are decentralized insofar as network configuration is not achieved by any central authority, but rather by means of a specific mesh routing protocol which automatically organises and coordinates network resources through a decentralized approach. In this sense, the transmission of packets does not rely on any predetermined route; the route is dynamically established by every node connected to the network who repeatedly communicates with some of its neighboring nodes to figure out what is the best route, at any given moment, to transfer packets through the network (De Filippi \& Tréguer, 2014).

To the extent that mesh networking requires people sharing their Internet connection to third parties, are these emerging practices potentially affected by the HADOPI law? In order word, shall individuals voluntarily sharing their Internet connection and providing a gateway for people to connect anonymously to the Internet be held liable of gross negligence for failure to secure the access to their Internet connection?

The law stipulates that, unless there are "legitimate motives" justifying the lack of securitization, the subscriber to an Internet connection is to be held liable for any copyright infringement stemming from such connection. The tort of gross negligence can thus be regarded as a means for the State to extend its sovereignty over community mesh networks (which are, by virtue of their decentralized character, inherently difficult to regulate) by delegating to the subscribers of an Internet connection the task of policing the network so as to avoid liability on their part. The result is, of course, a lower incentive for people to share their Internet connection to the public at large and, consequently, a reduction in the number of users that will contribute their own resources to support the operations of community mesh networks.

This is a good illustration of how the HADOPI law might come with a series of unintended consequences that go well beyond the intended scope of the law. While it is questionable whether or not the legislator had actually foreseen this problem (i.e. whether this result was premeditated or not), it appears, nonetheless, that the law has eventually shifted away from its original focus on copyright infringement, to cover other legitimate activities that do not have anything to do with online piracy. Indeed, the HADOPI 
law was never meant to restrict or even regulate the use and deployment of community mesh networks; yet, as an attempt to counter copyright infringement, the three-strikes regime indirectly (and negatively) affected the ability for people to share their Internet connection freely and anonymously. The consequence is a restraint on the ability for users to communicate with each other in a way that is both anonymous and autonomous (i.e. that does not require passing through a centralized authority or ISP in order to connect to the Internet).

\section{Conclusion}

As a general rule, estimating the success of the law is a subjective task, which is ultimately a matter of perspective and degree. Yet, it might be possible to come up with more objective assessment by comparing the actual impact of the law against the intended impact of the law. This requires analysing not only the extent to which the law succeeded in regulating what it was meant to regulate, but also the effects it had on what it was actually not meant to regulate.

With regard to the French HADOPI law, if one considers the intention of the legislators in charge of implementing the law, it is difficult to deny that they have actually failed in their intent of decreasing the rate of online copyright infringement. It would seem, indeed, that the graduated response missed its original target (that of discouraging copyright infringement) and hit a different target instead. Originally meant to dissuade potential infringers from illegitimately transferring copyright protected files over peerto-peer file-sharing networks, the three-strike regime has been implemented into French legislation in such a way that it might end up harming the interests of the public at large.

In this paper, we presented the HADOPI law as a prototypical example of legislative serendipity producing a lot of unintended and perverse effects. Indeed, not only did it fail at putting an end to the unauthorized exchange of digital content, it also caused damages to the users of peer-to-peer file-sharing networks (including those who legitimately use them for the exchange of files that does not give rise to copyright infringement) whose privacy has been severely injured by the practices of mass surveillance that emerged onto these networks.

Besides, by making users liable for sharing their Internet connection in a non-securitized manner, the HADOPI law also had a series of negative externalities or unintended effects on other types of activities which are not directly connected with the issues of copyright infringement (and which are thus rarely taken into account, simply because they stand outside of the scope of the law).

It can sometimes be very difficult to assess the negative impact that specific laws or regulations had on different sectors of activity, especially when it comes to measuring the damages resulting from the "loss opportunities" caused by these laws. Yet, it could be argued that, by introducing the tort of gross negligence for failure to secure one's Internet connection, the law effectively reduced the incentives for people to deploy alternative networks structures based on community participation and cooperation thereby precluding or, at least, significantly limiting the deployment of community mesh networks, and consequently reducing the opportunities for the establishment of a more grassroots and decentralized approach to the currently centralized Internet infrastructure.

Ever since its creation in 2009, the efficiency and constitutionality of the HADOPI law has been constantly put into question, and the law has been subject to a series of reforms and amendments to try and resolve these concerns. It is only in 2013 that the French government eventually admitted that such 
implementation of the three-strike regime had actually been a mistake: not only did it fail to achieve the expected results with regard to copyright infringement, but it also went counter to the concept of sharing and collaboration that characterise most of the emerging practices online. Besides, the HADOPI agency, although ineffective, was very costly to operate.

On July 8th, 2013, the provisions of the HADOPI law allowing to terminate the Internet connection of of alleged individual infringers were abrogated by law decree $\mathrm{n}^{\circ} 2013-596 .^{37}$ The law was amended to remove the "additional misdemeanor punishable by suspension of access to a communication service" on the grounds that preventing subscribers from accessing the Internet because of alleged copyright infringement was a disproportionate measure that impinges upon human rights. Yet, the provisions establishing possible fines (up to 15000 euro in the case of gross negligence) for copyright infringement have been preserved, along with the obligation for ISPs to disclose personal information concerning alleged infringers. Finally, given the overall inefficiency of the procedure, the French Ministry of Culture declared in a press release ${ }^{38}$ that the HADOPI would no longer be in charge of overseeing the process of graduated response, and that the implementation of the three-strike regime will be transferred instead to the national media regulator, the Conseil Supérieur de l'Audiovisuel.

This is might be regarded as a sign that the law is evolving towards a more sensible solution. And yet, if we look at the details of the suggested reform, it appears that it might actually turn out to be much worse for end-users. Surely, a temporary suspension of one's Internet connection is no longer possible under the new three-strike regime, but what will it be replaced with? One possible solution - promoted by the creative industry and, in particular, by the French Union of Independent Phonogram Producers (UFPI) - is to introduce a systematic fine (of about 140 euros) that every subscriber shall pay whenever his or her Internet connection is used for the purposes of copyright infringement[@@Ref]. In other words, the idea is, again, to complement (or perhaps supplement) the criminal charges for copyright infringement (which require on a long and bureaucratic procedure of warnings and notifications, as well as the intervention of a judge in order to inflict the penalty) with a system of administrative sanctions that can be issued directly by the HADOPI itself, or by its successor the CSA. This ultimately means shifting away from a criminal liability rule, towards a civil liability rule based on the automatic imposition of a fine upon every ascertained infraction (just like it is currently done with speeding tickets and other civil liability torts).

The graduated response is evolving, indeed; but while it is apparently becoming less strict and oppressive (as the ultimate penalty of disconnection has been revoked), in practice, if such a model of systematic fines were to be approved by the Constitutional Council, the resulting regime would end up being much more intrusive than the original three-strike regime. Again, France seems to be a pioneer in this field, with the introduction of new legislative measures which might actually go counter the traditional principles of law (in terms of due process and the presumption of innocence) and might eventually lead to a number of unintended consequences that yet cannot be foreseen.

37 Décret $n^{\circ}$ 2013-596 du 8 juillet 2013 supprimant la peine contraventionnelle complémentaire de suspension de l'accès à un service de communication au public en ligne et relatif aux modalités de transmission des informations prévue à l'article L. 331-21 du code de la propriété intellectuelle.

${ }^{38}$ Publication du décret supprimant la peine complémentaire de la suspension d'accès à Internet du 9 juillet 2013. 


\section{References:}

Anciaux, A. (1995). "Les résultats inattendus (effets sérendips) du RMI et du Minimex", Journée d'étude sur l'insertion, Conseil Géneéral, Départementdu Nord, Conseil départemental d'insertion, 22 février 1995.

Arnbak, A., \& Goldberg, S. (2014). Loopholes for circumventing the constitution: Warrantless bulk surveillance on americans by collecting network traffic abroad.

Arnold, M. A., Darmon, E., Dejean, S., Pénard, T. (2014) Graduated Response Policy and the Behavior of Digital Pirates: Evidence from the French Three-Strike (Hadopi) Law. Available at SSRN:

http://ssrn.com/abstract=2380522

Barker, J. (2004). Grossly Excessive Penalties in the Battle Against Illegal File-Sharing: The Troubling Effects of Aggregating Minimum Statutory Damages for Copyright Infringement. Tex L. Rev., 83, 525.

Beniger, J. (2009). The control revolution: Technological and economic origins of the information society. Harvard University Press.

Boorstin, E. S. (2004). Music sales in the age of file sharing (Doctoral dissertation, Princeton University) Boudon, R. (1991). La place du désordre, Paris, PUF, 1991, p. 184-190.

Bourcier, D. (2011) "La sérendipité du droit", in D. Bourcier \& P.Van Andel (eds), La sérendipité, le hasard heureux, Paris, Hermann, pp. 173-183.

Danaher, B., Smith, M., Telang, R., Chen, S. (2012) The effect of graduated response anti-piracy laws on music sales: evidence from an event study in France. Available at:

https://www.scribd.com/doc/79271399/Hadopi-Final

Dejean S., Pénard T., Suire, R. (2010) Une première évaluation des effets de la loi Hadopi sur les pratiques des Internautes français. Université de Rennes, Laboratoire M@rsouin. The full study is available at http://www.marsouin.org/lMG/pdf/NoteHadopix.pdf

De Filippi, P., Tréguer, F. (2014). Expanding the Internet Commons : The Subversive Potential of Wireless Community Networks, in Journal of Peer Production (forthcoming).

Dobusch, L., \& Schüßler, E. (2014). Copyright reform and business model innovation: Regulatory propaganda at German music industry conferences. Technological Forecasting and Social Change, 83, 24-39.

Fisk, N. W. (2009). Understanding online piracy: the truth about illegal file sharing. Praeger Publishers. Giliker, P. (2010). Vicarious liability in tort: a comparative perspective (Vol. 69). Cambridge University Press.

Ginsburg, J. C. (2002). Essay: From Having Copies to Experiencing Works: The Development of an Access Right in US Copyright Law. J. Copyright Soc'y USA,50, 113.

Heide, T. (2000). Copyright in the EU and US: What Access-Right. J. Copyright Soc'y USA, 48, 363. Herweijer, M. \& Winter, H. B. (1995). "Evaluation of legislation: change or improvement?" in W.J.M. Kickert \& F.A. van Vught (eds) Public policy \& Administration Sciences in the Netherlands, London, Prentice Hall

Huygen, A., Rutten, P., Huveneers, S., Limonard, S., Poort, J., Leenheer, J., ... \& Helberger, N. (2009). Ups and Downs: Economic and cultural effects of file sharing on music, film and games.

Kim, W. C., \& Mauborgne, R. (1999). Strategy, value innovation, and the knowledge economy. Sloan management review, 40, 41-54.

Lessig, L.. (2004). Free culture: How big media uses technology and the law to lock down culture and control creativity. Penguin.

Lucchi, N. (2011). Regulation and control of communication: the French online copyright infringement law (HADOPI). Cardozo Journal of International and Comparative Law (JICL), 19, 11-07.

Lev-Aretz, Y. (2013). Copyright Lawmaking and Public Choice: From Legislative Battles to Private Ordering. Harvard Journal of Law \& Technology. Volume 27, Number 1. Fall 2013

Litman, J. (2001). Digital copyright. Prometheus books. 
Mayton, W. T. (1984). Seditious Libel and the Lost Guarantee of a Freedom of Expression. Columbia Law Review, 91-142.

Massaro, T. M. (1990). Equality and Freedom of Expression: The Hate Speech Dilemma. Wm. \& Mary L. Rev., 32, 211

Mell, P. (2002). Big Brother at the door: Balancing national security with privacy under the USA PATRIOT Act. Denv. UL Rev., 80, 375.

Merton, R. K. (1936). The unanticipated consequences of purposive social action. American sociological review, 1(6), 894-904.

Peukert, C., Claussen, J., \& Kretschmer, T. (2013). Piracy and movie revenues: evidence from megaupload.

Poort, J., \& Rutten, P. (2010). Legal, economic and cultural aspects of file sharing. Communications \& Strategies, 1(77), 35-54.

Tehranian, J. (2007). Infringement nation: Copyright reform and the law/norm gap. Utah L. Rev., 537.

Ten Heuvelhof, E. F., \& de Bruijn, J. A. (1995). Governing: structure and process-contingent interventions. Public Policy and Administration Sciences in the Netherlands, London: Prentice Hall, 163176.

Stefancic, J., \& Delgado, R. (1992). Shifting Balance: Freedom of Expression and Hate-Speech

Restriction, A. lowa L. Rev., 78, 737.

Van Andel, P. \& Bourcier, D. (2012). De la sérendipité, dans la science, la technique, l'art et le droit, Paris, Hermann, 2012 (2nd edition).

Walpole, H. (1754). Three princes of Serendip. Fairy Tale, mid-XVIII Century.

Zhang, Y., Luo, J., \& Hu, H. (Eds.). (2006). Wireless mesh networking: architectures, protocols and standards. CRC Press.served 